
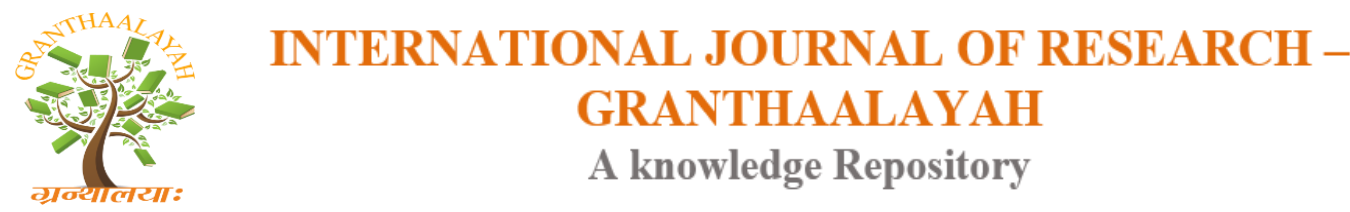

Science

\title{
SOLAR ENERGY FOR GREEN INDIA
}

\author{
D. P. Jesudoss Manohar ${ }^{* 1}$, Dr. T. Jayaprakasam ${ }^{2}$ \\ ${ }^{*}$ Research Scholar, Nehru Memorial College, INDIA \\ ${ }^{2}$ Principal, Nehru Memorial College, INDIA
}

DOI: https://doi.org/10.29121/granthaalayah.v4.i10(SE).2016.2464

\begin{abstract}
India a rapidly growing economy with more than 1 billion people is facing a huge also energy demand. The electricity production has expanded over the years but we cannot deny the fact that the population of the country is also expanding. More than $72 \%$ of population living in villages and half of the villages remain without electricity. It's high time that our country should concentrate more on energy efficiency, conservation and renewable energy to fulfill the energy needs of India and bridge the energy demand-supply gap.
\end{abstract}

Keywords:

Solar Energy, Green India, Green Energy, Electricity.

Cite This Article: D. P. Jesudoss Manohar, and Dr. T. Jayaprakasam, "SOLAR ENERGY FOR GREEN INDIA" International Journal of Research - Granthaalayah, Vol. 4, No. 10: SE (2016): 21-24.

\section{INTRODUCTION}

India is among the top 5 countries in the world in terms of energy consumption and generation. Coal and oil are the two most widely used sources of energy in India, with natural gas, hydro and nuclear sources being far behind. Coal and oil are likely to remain the major energy sources in India even in 2030 though the share of natural gas, hydro and nuclear is projected to increase.

India being a net importer of oil and gas due to low internal reserves faces the challenge of ensuring energy security to fuel its economic growth. Indian coal reserve is typically of low quality which necessitates import of high quality coal and it is predicted that country's coal reserves won't last beyond 2040-50. The issue of climatic change has come under sharp focus among the international community in recent years. With India featuring among the top 5 polluters in the world in terms of absolute greenhouse gas emissions International pressure on India to reduce its emissions has been growing over the last few years. 
The objective of this paper is to explore various problems due to use of conventional energy sources. An effort is made to conduct a diagnostic study on the situation of problems in current energy scenario. It recommends the solar energy now sought to promote the concept of green energy.

\section{PROBLEMS OF COAL ENERGY}

Coal energy is producing tremendous amount of carbon emissions that results in climate change and global warming. Coal burning is considered not environmental friendly due to the production of harmful by-products like nitrogen, carbon di oxide and sulfer dioxide. Coal burning can cause pollution to the environment like acid rain. Coal energy is fast depleting because many people consume a large amount of it inefficiently. This form of energy is not renewable one. It is also ruining the ecosystem and environment and putting many people's lives in danger miners. Underground mining is very hazardous because cave-ins and explosions are common. Unstoppable damages could occur when mining coals.

\section{PROBLEMS OF HYDRO ELECTRIC POWER}

It can be generated only in areas with heavy rainfall and sufficient supply of water. Hydel power generation stations are to be located in hilly mountainous terrains where waterfalls as well as ideal sites for dams are located. In a region without hills hills hydel power generation is not possible. Loss during transmission is very high, sometimes up to $30 \%$. Dams are expensive to build. Building a dam effects the environment and wildlife of adjoining areas. Nearby low lying areas are always under the threat of floods. Building of dams causes lot of pollution. Erosion sediment is retained behind the dam so that the banks downstream of dams judgments are subject to erosion. If rains are scarce, there might not be enough water to turn turbines. Sobatage or terrorism threats to the safety area is another drawback of water power. Changing the river pathway shortage of water can cause serious disputes between the people. Making dams on rivers affect the amount, quality and temperature of water that flow in streams which has drastic effects on agriculture and drinking water. The water while flowing through the dam collects nitrogen which can damage and also kills fish. They can also damage the reproduction of fishes thus eliminating the whole species of fish.

\section{PROBLEMS OF NUCLEAR ENERGY}

Radioactive minerals are unevenly distributed around the world and found in limited qualities. Supply of high quality uranium, one of the raw materials, will last only for few decades. Nuclear waste from nuclear power plant creates thermal pollution which may damage the environment. A large amount of nuclear waste is also created and disposal of this waste is a major problem, the danger of accidental discharge of radio activity also exists. Starting a nuclear plant requires huge capital investment and advanced technology. Nuclear plants are opposed on moral grounds, by many groups, because of their close linkage with development of nuclear weapons. There are number of restrictions on the export or import nuclear technology fuels etc., Nuclear power stations are always at the risk from terrorist attack. Proliferation of nuclear technology increases the risk of nuclear war too. The waste products remain active over many years and disposing it safely is an issue which needs to be addressed properly. Nuclear power is not a renewable source 
of energy. Uranium is a metal that is mined from the ground in much the same way as coal is mined. It is a scarce metal and the supply of uranium will one day run out making all the nuclear power plants obsolete.

The industrial revolution, which started a couple of hundred years ago, produced all sorts of technology that made an Enormous impact on people's lives. Now we are about to go through another period of major change, where we shift from relying on carbon intensive sources of energy such as oil and coal. Evidence is showing that burning oil and coal is contributing to global warming. So we need new clean energy ideas to keep up with our demand for electricity without damaging our environment.

\section{NEED FOR SOLAR ENERGY}

Fuel depletions and climate changes have driven us to an energy crisis. This has made us realize the urgency for finding alternative source for quenching the ever growing demand for energy. The conventional source of energy is all mostly non-renewable sources of energy. Their extensive usage has caused their known reserves to be depleted rapidly. In India alone the known deposits of petroleum are envisaged to last only a few decades, whereas coal reserves will last for just hundred years. Solving this energy crisis needs combined efforts from economies all over the world, which is possible only with universal support from the ruling governments. The rising costs of energy have started to force global leaders to realize the importance of research on alternative sources of energy.

Solar is the Latin word for sun - a powerful source of energy that can be used to heat cool and light our homes and businesses. That's because more energy from the sun falls on the earth in one hour than is used by everyone in the world in one year.

India has tremendous scope of generating solar energy. The geographical location of the country stands to its benefit for generating solar energy. The reason being India is a tropical country and it receives solar

\section{ADVANTAGES OF SOLAR ENERGY IN INDIA}

Some of the advantages of solar energy which makes it all the more suitable for India is as follows; there is an inexhaustible source of energy and the best replacement to other non-solar energy is environment friendly. When in use, it does not release $\mathrm{CO} 2$ and other gases which pollute the air. Hence it is very suitable for India, India being one of the most polluted countries of the world. Solar energy can be used for variety of purposes like as heating, drying, cooking, or electricity, which is suitable for the rural areas in India. Solar energy can be used for variety of purposes like as heating, drying, cooking or electricity, which is suitable for the rural areas in India. It can also be used in cars, planes, large power boats, satellites, calculators and any more such items, just apt for the urban population. Solar power is inexhaustible. In energy deficient country like India, where power generation is costly, solar energy is the best alternate means of power generation. A solar energy system can be installed anywhere. Solar panels can be installed anywhere. Solar panels can be easily placed in houses. Hence it is quite inexpensive compared to other sources of energy. Getting solar energy is so natural and also it is compact it can be 
installed a whole load of bulky equipment. Solar energy can be stored in solar panels so that we can use solar energy even when it is not sunny outside. If used solar energy will be of a great technological innovation.

\section{CONCLUSION}

Solar energy can bridge the gap between demand and supply of power. The solar energy is a viable and better renewable energy to conventional energies like thermal and hydel power. No wonder many scientist and policy makers are searching for ways to make solar energy a larger part of our energy strategies in the future.

\section{REFERENCES}

[1] TERI (2011): Towards Energy Security, 10 January, accessed on 15 Jan 2011(www.teri.in.org)

[2] Singh Manmohan(2010): To create solar Village, Jan, Solar Energy Review, New Delhi

[3] Chatterjee, Pramita(2010): For Clean Green Energy, Economic Times, October 1st, pp-7

[4] Delhi International Renewable Energy Conference (DIREC-2010): accessed on 12 Dec, 2010 (http:/www.direc2010.gov.in/)

[5] US-India Energy Partnership Summit, Washington DC(2010); Solar Energy Review, New Delhi-India

[6] http://www.energymile.com

[7] http://www.worldenergyoutlook .org/8.www.pcra.org. 